\title{
Women, Enclosure and Estate Improvement in Eighteenth-Century Northamptonshire
}

\author{
B R I O Y A. K. M c D O N A H \\ History Department, University of Sussex, Falmer, Brighton, BN1 9SH, UK
}

\begin{abstract}
This paper examines the role of elite women in estate management, enclosure and landscape improvement in eighteenth-century England, a topic which has to date received little in the way of sustained academic consideration. The paper focuses on four women who took control of sizeable Northamptonshire estates in the 1760 s and early 1770 s, and demonstrates that these women were active as both managers and innovators. In examining the women's involvement in estate management, the paper explores a series of important questions about women's place in the history of parliamentary enclosure and landscape improvement, as well as women's role in eighteenth-century society more generally.
\end{abstract}

\section{Introduction}

This article sets out to demonstrate that elite women were active in estate management, enclosure and improvement in later eighteenth-century England, a topic which has so far received little in the way of sustained academic consideration. This is perhaps surprising, given the growing body of literature on aristocratic, gentle and middle class women's participation in a variety of areas traditionally seen as the preserve of men, including politics, electioneering and activism in the anti-slavery movement. ${ }^{1}$ Nowhere has this been truer than in accounts of women's relationship to the economy. While middle class women's widespread contributions to family businesses and book-keeping have long been acknowledged, historians have recently drawn attention to single and widowed women's independent involvement in business enterprises and formal credit provision via annuities, mortgages and other types of loans. ${ }^{2}$ Other scholars have brought to light substantial groups of women investing for income or capital growth in the stock market, particularly in government securities and the shares of railway and canal companies, who thereby contributed to Britain's industrial and economic development both at home and overseas. ${ }^{3}$ Historians have also highlighted the contributions to household economies made by the wives and daughters of farmers, labourers and artisans. This included both paid employment as day labourers and outworkers in the handicrafts industries, and unpaid work like dairying, caring for animals and tending cottage gardens. ${ }^{4}$ At the same time, the extent, timing and regional nature of any decline in women's employment 
opportunities during the industrial revolution has been widely debated, as has the impact this had on women's status within wider society. ${ }^{5}$

Yet far less has been written about aristocratic and gentle women living in rural areas and the part these women played in managing family estates. Instead research on elite women has generally focused on their role in country house and garden design, in part because gardening was undoubtedly a popular female activity and gardens, like houses, have often been thought of as enclosed feminine spaces. ${ }^{6}$ This is not to suggest that great houses were purely private spaces which kept women isolated from the world beyond the park pale. Hospitality, consumption and letter-writing all linked women into the public and political world, while household management represented an 'exercise of power' by gentlewomen which paralleled their husband's work on the wider estate. ${ }^{7}$ Another way women were connected to wider estate landscapes was through their participation in charitable projects. For example, Ruth Larsen has recently highlighted the case of the unmarried Gascoigne sisters of Lotherton Hall (Yorkshire) who built schools, almshouses and soup kitchens on their estates in Yorkshire and County Limerick, Ireland. Trevor Lummis and Jan Marsh have drawn attention to the philanthropy of Elizabeth Chute at the Vyne (Hampshire), while Stella Tillyard has cited the example of Louisa, Duchess of Connelly who as a widow gained control of a large estate and put it to use building a church and school. ${ }^{8}$ Yet by focusing almost exclusively on the spaces in which women are traditionally seen to have been active, historians have tended to overlook elite women's involvement in estate management and agricultural improvement, areas which have generally been thought of as distinctly 'male' spheres of activity.

Amy Erickson has recently demonstrated that despite coverture and primogeniture, women actually controlled significant amounts of property as widows and co-heiresses. ${ }^{9}$ Yet historians have been slow to investigate female landowners' roles in estate management, in part because of the difficulties in accessing women's 'hidden histories'. This neglect also stems from the fact that gentle and aristocratic women seen to have been active in seventeenth-century farm management are understood to have increasingly retired into domesticity, or even idleness, in the eighteenth century. ${ }^{10}$ The chronology and causes of women's supposed retreat into the private, domestic sphere have been widely debated over the last twenty years, but some historians have suggested that the commercialisation of farming and the enclosure of common land introduced an increasingly rigid division of labour and thereby contributed to the development of separate spheres for men and women. Such research has focused almost exclusively on the impact enclosure had on working women and commoners. ${ }^{11}$ But what about the propertied women whose estates were being enclosed? What did it mean for women to exploit and master the land, in an era that was arguably characterised by an ongoing project to place, or even enclose, women within the private, domestic sphere?

In an attempt to answer these questions, the paper focuses on four women who took control of sizeable Northamptonshire estates in the 1760s and early 1770s. The paper begins by discussing the women's place within their families and the circumstances by which they became landowners, and then moves on to examine the women's involvement in estate management, enclosure, agricultural improvement and landscaping. The final section offers some concluding comments. 


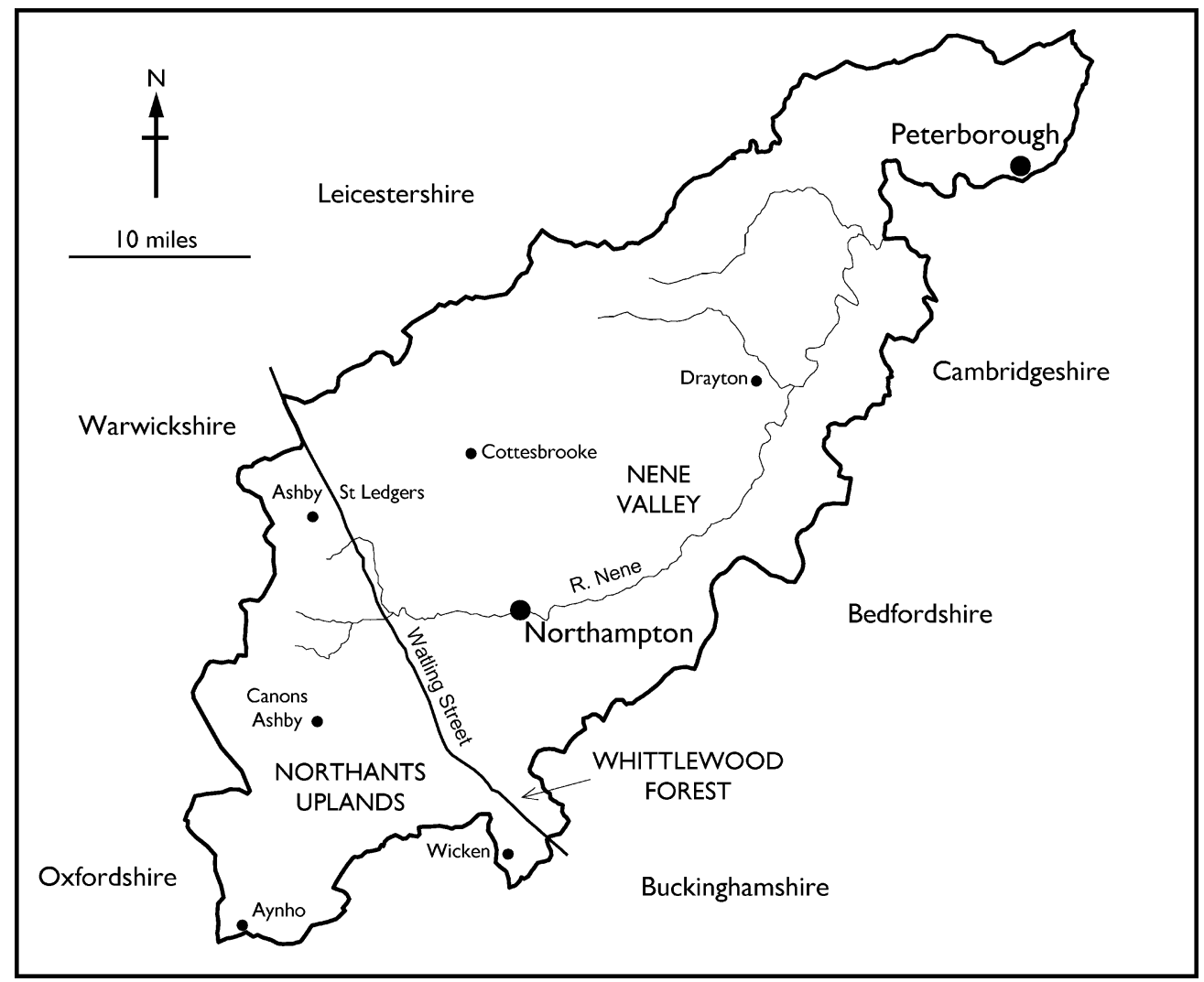

Figure 1. The historic county of Northamptonshire

\section{Families and Estates}

By coincidence, the estates belonging to the female landowners discussed here all lay in western Northamptonshire west of Watling Street, the area most affected by the first great upturn of parliamentary enclosure in the county in the second half of the eighteenth century (see Figure 1). In the early modern period this rural region was characterised by two main landscape types, both based on heavy but fertile clay soils. The Northamptonshire Uplands was a landscape of nucleated villages, while to the south-east in the Whittlewood Forest the landscape was more heavily wooded and settlement types far more varied. For example, Wicken was a nucleated village but the parish included several dispersed settlement elements, and there were numerous medieval assarts and woodland coppices as well as an open field system. Both regions were characterised by a mixed agrarian economy into which sheep farming made significant inroads in the early modern period. Thus the region was marked by a mix of open field systems and early enclosures for permanent pasture, some of which were associated with deserted settlement sites. $^{12}$

The remaining open field systems in western Northamptonshire were mostly enclosed by parliamentary act in the second half of the eighteenth century, and the women discussed 
here were in charge of their estates either at the time of enclosure or in the years immediately following. As is well known, Northamptonshire experienced particularly high levels of parliamentary enclosure: between 1727 and 1841, 213 enclosures took place in the county by means of a parliamentary act, and others, like Wicken, were achieved by more or less formal agreements. ${ }^{13}$ The pace of enclosure was at its peak in the 1770 s and again in the early nineteenth century, and the estates discussed here were all enclosed in the earlier phase of parliamentary enclosure in the county. ${ }^{14}$ Thus the women studied in this article lived in a rapidly evolving landscape.

The women were all significant landholders, albeit not members of great aristocratic families. ${ }^{15}$ All the women were widows whose husbands had made provision for them in the form of either jointure estates or more individualised arrangements. In the medieval period widows had dower rights to one third of their deceased husband's real property under the common law. Such dower rights had been largely superseded by jointure arrangements by the sixteenth century, whereby the cash portion women brought into marriage was used to buy land which would provide an annual income for her in widowhood. ${ }^{16}$ Yet most of the women discussed here did not have children and, perhaps because there was no immediate heir to inherit the main property, they gained control of landed estates rather than being provided for by means of an annuity or cash payment.

The model woman in early modern England was a good wife, prudent housekeeper and caring mother. Childless marriages were usually thought of as sad marriages and infertility typically seen to be the woman's fault. ${ }^{17}$ In this sense, most of the women examined here had failed in their social and familial duty to provide an heir to the estate, a fact which may have affected their willingness and ability to manage landed estates. Childless widows did not of course have responsibilities to young children and as a result, may have had more time to devote to estate management. On the other hand, they were managing the estate on behalf of a more or less distant male relative whom they may or may not have met. For example, Mrs Jane Ashley probably never met the man who inherited the estate at her death in 1784 . As the least wealthy woman discussed here, she controlled 1,300 acres in Ashby St Ledgers under her marriage settlement, amounting to just over two-thirds of the parish. Her father-in-law had made his fortune as a London draper before buying the estate in 1703 and his son had consolidated the family's place in local society by becoming Sheriff of Northamptonshire in $1756 .{ }^{18}$ Jane and her husband did not have children, and the heir to the estate was her husband's cousin's son Joseph Ashley of Broughton (Cumbria), who despite promising to visit Jane in Ashby St Ledgers, seemingly never did so. ${ }^{19}$

Mrs Elizabeth Prowse had a very different relationship with the eventual inheritor of the estate at Wicken. Elizabeth was the widow of George Prowse, the son of a Somerset MP who had inherited the estate from his mother's family of London merchants who purchased the Wicken estate in 1716. Elizabeth and George had no children and at Elizabeth's death in 1810 the estate at Wicken passed to George's nephew Charles Mordaunt. Unlike Jane Ashley, Elizabeth was closely involved in the lives of her nephews and nieces, exchanging regular visits with them at Walton (Warwickshire) and noting their births, inoculations and childhood illnesses in her memoirs. ${ }^{20}$ Elizabeth's brother-in-law, Sir John Mordaunt, heir apparent to the estate until his death in 1806, visited Wicken in 
1796 and negotiated with the tenants over tithe payments, and his younger son John was appointed by Elizabeth as rector of Wicken in $1798 .{ }^{21}$ Yet despite the apparent closeness between the Mordaunt family and Mrs Prowse, Charles nonetheless had to wait until his aunt's death in 1810 to inherit the estate, by which time he was aged almost forty.

The decision to grant the Wicken estate to Elizabeth Prowse for life is an interesting one. When George Prowse died in 1767, there was no suitable male available to manage the estate: George had no brothers and his two younger sisters were unmarried teenagers living at home with their mother at Berkeley in Gloucestershire. Elizabeth's jointure of four hundred pounds per annum payable from Wicken effectively left her in charge of the estate, and her husband's family seem to have been happy to leave the property in her hands. ${ }^{22}$ The family situation was very different by 1772, when George's mother confirmed this arrangement by demising Wicken to Elizabeth for life in exchange for surrendering her jointure. ${ }^{23}$ By then, the elder of George's sisters, Betsy, had married John Mordaunt and given birth to a son Charles, the eventual inheritor of Wicken, in January $1771 .{ }^{24}$ In other words, Mrs Prowse senior demised the estate to Elizabeth for life despite the existence of legitimate heirs in the persons of her new son-in-law John Mordaunt and her baby grandson Charles. John Mordaunt admittedly had his own estates at Walton (Warwickshire) where he was resident, and the decision to grant Wicken to Elizabeth may reflect a desire to have a resident owner overseeing the estate. Moreover, given that Elizabeth was only thirty-nine in 1772 and might have reasonably expected to live for several more decades, the demise seems to reflect a sincere belief that she was capable of managing Wicken for the benefit of the eventual Mordaunt inheritor.

The other two women with whom this paper is concerned married into more established Northamptonshire families. Lady Elizabeth Dryden of Canons Ashby was the widow of a baronet from an ancient pedigree, although his branch of the family had only recently inherited the title and the estate. Sir John and Lady Dryden did not have children but they solved their childlessness by adopting their niece, the eldest daughter of Sir John's youngest brother Bevill Dryden. Bevill had died in 1758, leaving his pregnant wife Mary and three daughters in financial difficulties. Mary gave birth to another daughter in January 1759 and a year later Sir John wrote his sister-in-law offering to raise her eldest daughter Elizabeth at Canons Ashby. ${ }^{25}$ Mary Dryden accepted Sir John's offer and the seven-year-old Betsy, as Sir John and Lady Dryden quickly came to call her, arrived at Ashby in March 1761. Lady Elizabeth wrote to her sister-in-law on the day of her niece's arrival reporting they were both 'mightily pleased with her' and promising that 'all the care shall be taken of her in every respect, $\&$ her good consulted in all particulars that are within my power' ${ }^{26}$ After a few early troubles, the little girl seems to have quickly settled in, and Sir John and Lady Dryden were said to be 'violent fond of her'. ${ }^{27}$ They described her as 'a child after our own hearts' and Sir John reported to his sister-in-law a month after the little girl's arrival that 'Indeed I am as well pleased as if it was a Boy'. ${ }^{28}$

None of Sir John's four brothers had any male children and Betsy was obviously adopted with the intention of making her heir to the Dryden estates. Under Sir John's 1770 will, the Dryden estates passed to Lady Elizabeth for life, and after her death were to be held in trust for his niece. After Betsy's death, they would descend to her male heirs, 
with the proviso that the eventual inheritor would change his name to Dryden. ${ }^{29}$ Betsy later married Sir John Turner of Ambrosden (Oxfordshire), and he accordingly changed his name to Dryden in 1791, the year he inherited the Dryden estates at the death of his wife's aunt. Like Mrs Prowse, Lady Dryden was not willing to give up her rights for life in the estate, even to her adopted daughter and her husband.

The final woman discussed in this paper is Mrs Mary Cartwright. She was the widow of Thomas Cartwright, another MP's son whose family had held the manor of Aynho since the early seventeenth century, along with property in the surrounding townships, in Oxfordshire and in Surrey. Thomas died in his mid thirties, leaving his widow to care for their young daughters and baby son, William Ralph Cartwright. Unlike the childless women discussed above, Mary remarried, and she and her new husband Sir Stephen Cotterel managed the Cartwright estate as trustees during William's long minority. ${ }^{30}$ Like all the other women examined here, the Cotterels kept excellent records. It is by using documents concerned with the financial administration of the estate including accounts and rentals, household and personal ledgers, alongside more personal items such as correspondence and memoirs that we can hope to reconstruct the world of the eighteenth-century landowning women.

\section{Estate Management, Enclosure and Improvement}

On Thursday 20th August 1767 George Prowse, lord of Wicken, succumbed to a fever. He died five days later at three o'clock in the morning and was buried at the family's ancestral seat at Axbridge (Somerset). Reflecting back on George's death as she wrote her memoirs more than forty years later, his widow Elizabeth still considered it, 'The very greates[t] shock and affliction I ever received'. ${ }^{31}$ Regardless of the emotional trauma of losing her husband, Elizabeth must also have felt daunted by the responsibility she now bore for managing the family property. She and George had been in residence at Wicken for just three years, and at the age of thirty-four she found herself a widow who must quickly apply the skills she had learnt in supervising the household to running the wider estate.

Elizabeth's ledgers begin in May 1768, nine months after her husband's death. The three surviving volumes cover the periods 1768 to 1771 and 1774 to 1784 , and include what might be broadly thought of as personal, household and estate accounts. Personal clothing, travel and pocket expenses were accounted under separate headings, as were Elizabeth's meticulous records of money she was owed by various relatives and friends. The household accounts were organised under a variety of headings including expenses for general housekeeping, linens, coal, servants' wages and clothing, the stables, cellars and repairs to the house. The cook's and steward's expenses were accounted separately, as were those of several of the other servants and some of the farmers. The estate accounts were organised under three main headings: firstly, the expenses of the farm in hand including a detailed record of the sums raised from the sale of butter, cheese, wool, livestock and grain; secondly, the expenses of the cottages; and thirdly, the Wicken estate, including money spent on the tenants' farms. 
The first year's entries are in a hand other than Elizabeth's, possibly that of her brother James Sharp or her steward Joseph Foxley. Elizabeth acted as housekeeper for James in London before her marriage, and it is tempting to suggest that he returned the favour by helping her to manage the estate and keep her accounts in the first year of her widowhood. Yet by May 1769, Elizabeth had assumed responsibility for keeping the estate, household and personal accounts and the remainder of the ledgers are written in her hand. Alongside these accounts, Elizabeth also kept a detailed cash book and two notebooks, discussed in greater detail below, in which she recorded information about the history and management of the Wicken and Grafton Park estates. ${ }^{32}$

Another widow who kept detailed estate accounts was Lady Elizabeth Dryden, who managed the large estate centred on Canons Ashby between 1770 and 1791. Despite an avowed dislike of writing letters, the ledgers are written in her hand and cover the entire period of her management. ${ }^{33}$ In one book she recorded her annual outgoings against her yearly income including her tenants' rents and the sums she raised from the sale of underwood, bark and hay from the home farm and woods. ${ }^{34}$ Another book for the same period was organised by tenant rather than by year, and recorded the rents paid to her on a half-yearly basis, along with various memoranda concerning their tenancies. ${ }^{35}$

Lady Dryden raised the rents on the much of the estate within six months of her husband's death, although most of the rent increases were relatively modest. Attempts to reorganise the tenancies were also more limited than at Ashby St Ledgers (discussed below) and were apparently initiated by the tenants or estate steward rather than Lady Dryden, who noted in her estate ledger:

Mr Wilson has taken on Underwood's bargain except that Underwood keeps Thorney Close \& meadows the rent $£ 29.10 .0$ which remainds in his hands. Harris has taken part of Underwood's bargain which I do not understand. ${ }^{36}$

Her writing became increasingly untidy as she grew older, but she still kept her accounts even as an old woman. We know from a letter written to her niece that she suffered a stroke in 1790, and the final year's entry was evidently written after this. This is testimony to Lady Dryden's sheer determination to record and audit the estate finances, but also definitive evidence that she kept her own accounts rather than relying, as might be expected, on her steward.

It is clear that these women intended their accounts to act as a record for future generations of landowners and stewards. As mentioned above, Elizabeth Prowse kept detailed notebooks in which she recorded various memoranda about Wicken and the neighbouring Grafton Park estate, held in turn by her two sister-in-laws Mary Rogers and Elizabeth (Betsy) Mordaunt. The notebooks were apparently written in c.1801 to 1803 with a few entries added later. The longer Wicken notebook includes a list of presentations to the living and ownership of the manor from 1218 to 1806 , as well as notes on taxes, quit rents and other payments charged on the estates, notes on common rights in Whittlewood Forest, estimates of eighteenth-century population, a description of beating the parish bounds, and an account of bread and cake to be distributed by the rector on Cross Monday and Holy Thursday. ${ }^{37}$ Perhaps the best example of a note 
made explicitly to be of use to future landowners comes from the Grafton Park notebook. Here Elizabeth included a memorandum about a game deputation, followed by the note that:

Tho I suppose Mr Rogers \& my Sister has made Memorandums of every thing respecting this affair, I have named it here, as Grafton now Sir John Mordaunts in case, he should think it right to have any firther Notice or Security. ${ }^{38}$

Elizabeth clearly used these notebooks and other pocket- and letterbooks to construct her memoirs in 1809, and these therefore incorporate detailed notes on land transactions, including memoranda on land given by her mother-in-law to the turnpike trustees, encroachments on her freeboard at Wicken in 1774 and changes to the land tax on the estate in $1788 .^{39}$

These widows ran their estate with the same kind of prudent economy that was valued in their domestic housekeeping, keeping detailed estate accounts in which they carefully recorded their annual income from rents and the sale of produce and timber from the home farm against their annual spending. In consultation with their stewards, they might increase their tenants' rents in line with increases in the value of agricultural products or the demand for land, and thus maintain the financial viability of the estates they managed. In this sense, elite women who took on estate management due to a lack of immediate male heir arguably did more to bolster the social and economic order by maintaining the financial viability of the estate and the status of the family, than they did to challenge the gender order in stepping out of the house and on to the home farm.

This said, elite women sometimes played a more active role in increasing the value of landed estates and creating, rather than simply preserving, wealth which could be passed on to future generations of the family. This is particularly true where it can be demonstrated that women were involved in enclosure, rationalisation and other agricultural improvements on their estates. Yet evidence for women's role in enclosure and estate improvement is often very difficult to uncover. For example, very few women are recorded as lord of the manor in the parliamentary enclosure awards for Northamptonshire. Only around seven per cent of the awards for parliamentary enclosures in the county between 1727 and 1841 record a woman as the manorial 'lord'. In more than half of these cases, the property was held by the Crown, jointly by a husband and wife or by a group of male and female siblings. In only seven instances was there a sole 'lord' of the manor or, as in the case of Winwick (formerly Northamptonshire, now Cambridgeshire), two women jointly holding the property. ${ }^{40}$ Many of these women were relatively small landowners, and most did not produce the kind of historical archive necessary to reconstruct their activities on their estates.

The major exception to this is Mrs Jane Ashley, who managed the estate at Ashby St Ledgers for more than twenty years between her husband's death in 1761 and her own in 1784. Evidence for Jane's management of Ashby comes from the frequent correspondence she maintained with both her estate steward in Rugby (Warwickshire) and the family solicitor in London. The positions were held by brothers Thomas and Samuel Harris, with whom Jane had a long-standing and close relationship. ${ }^{41}$ Unfortunately, Jane's letters do not survive but the twenty-five or so letters addressed to Jane from Samuel and 
Thomas provide a valuable insight into her management of the estate in the twenty years after her husband's death.

From the letters it is clear that Jane was personally involved in managing the agricultural estate at Ashby. As well as collecting her rents in person and organising for repairs to her tenants' farms, Jane was actively involved in the enclosure. This had been first proposed during her husband's lifetime, but the petition was not presented to parliament until February 1764, more than two years after Jane had first been widowed. ${ }^{42}$ Jane maintained a frequent correspondence with Samuel Harris in London, who drummed up support for the bill amongst MPs and reported to her on its progress through parliament in the winter and spring of 1764. The bill seems to have encountered two main problems in its passage through parliament. Firstly, the only other major landowner objected to the enclosure because he believed it would increase the parish rates, and secondly, having got the bill signed by the major landowners, the vicar died just weeks before it was due to be presented to parliament. ${ }^{43}$

Yet for all the problems, Jane seems to have been an enthusiastic proponent of enclosure. In January 1764, she wrote to Samuel Harris reporting the profits she expected to make. Her letter does not survive, but in an undated reply written in mid January, Samuel responded, saying he was:

Glad to hear you are like to make so much advantage tho' I was always quietly certain of it - however I would not have this much talked of yet till the Act is gone through both houses. ${ }^{44}$

Gossip was, of course, thought of as a peculiarly feminine vice, and Samuel seems to have been worried that Jane would talk too freely about the financial advantages of enclosure. ${ }^{45}$ He was no doubt concerned that she would endanger the progress of the act through parliament by raising new objections from those who did not stand to profit so much.

The enclosure of the open fields finally went ahead in the autumn of 1764. Jane was by far the biggest landowner and received over ninety per cent of the land enclosed in Ashby. It is clear that Jane oversaw a major reorganisation of the tenancies in the wake of enclosure. There had been fifteen principal tenants in both 1750 and in c.1761, each holding a farm made up of open field strips, meadow and pastureland. ${ }^{46}$ Yet by 1784, the year of Jane Ashley's death, there were only ten principal tenancies. This is in part explained by the fact that Thomas and Richard Capell who had been accounted separately in c. 1761 were listed together in 1784, as were the three Cure brothers. But in at least two instances, holdings appear to have been amalgamated, if only temporarily. For example, William Montgomery had taken on Verney's farm in addition to his own by 1784, and Thomas and Richard Capell had taken on lands previously let to a man named Weddings. ${ }^{47}$

Rental incomes, which had remained relatively stable in the two decades before enclosure, increased significantly in the twenty years after. The fifteen principal holdings had brought in $£ 518$ in c. 1761 , but by 1784 rental income for the ten amalgamated farms had reached more than $£ 1115$. That is, rental income from the Ashby farms more than doubled in the twenty-three years Jane managed the estate. If we compare the c.1761 and 1784 rentals, we can see that despite the rent increases many of Jane's tenants remained on 
their farms or the farms remained with the same families. In other words, Jane successfully improved rents in the wake of enclosure without losing large numbers of tenants, as had been the case on the Grafton estate and elsewhere in Northamptonshire. ${ }^{48}$

Another woman involved in enclosure by parliamentary means was Mrs Mary Cartwright, later Cotterel, of Aynho in the extreme south-west of the county. Mary and her new husband Sir Steven Cotterel managed the estate on behalf of her son William and during his long minority they improved the estate by establishing new plantations and acquiring freeholds by means of a series of purchases and exchanges which brought most of the parish into Cartwright hands. ${ }^{49}$ This was all done with a view to enclosure and while William was away at university and on the grand tour in the early 1790s, Mary progressed with the enclosure in his absence and in his name. The enclosure commissioners' minute book, the only one to survive for the parishes studied here, tells us little about the part family members played in the enclosure, but we know from surviving correspondence that Mary instructed the estate steward to negotiate with the remaining freeholders about the appointment of an enclosure commissioner, and wrote to her son reporting their progress. The Act received the Royal Assent in April 1792 and when the estate was enclosed in the autumn it was William's name which appeared on the award. Yet William was still on the Continent and it was Mary who travelled to Aynho to see the new hedges laid out and the new farm houses erected, again writing to her son to tell him how things went on. ${ }^{50}$ In this sense, Mary's activities at Aynho form something of a 'hidden history' accessible only through careful archival research and by piecing together scattered and fragmentary sources.

By contrast, undoubtedly the best and most abundant evidence for agricultural innovation by an elite woman in eighteenth-century Northamptonshire comes from Wicken in the south of the county close to the Buckinghamshire border. Here Mrs Elizabeth Prowse managed a 2,200 acre estate for over forty years from her husband's death in 1767 to her own in 1810. This was the longest period of estate management by a woman in eighteenth-century Northamptonshire and during her forty-three-year widowhood Elizabeth tirelessly improved the house, park and estate.

Improvements at Wicken had actually begun shortly after 1716, when the Spencer family of Althorp sold the estate to a London merchant Charles Hosier. He immediately commissioned a survey of the estate, which resulted in a detailed map, and began buying up freeholds in the village. ${ }^{51}$ The following year, Hosier removed his household to a new mansion he had built in the former deer park, $1.3 \mathrm{~km}$ south of the church and medieval manor house. He converted the early seventeenth-century lodge built by the Spencer family into stables and removed hedgerows in order to re-establish the park around the new house. ${ }^{52}$ Hosier died in 1750 and the estate descended to his granddaughter Elizabeth and her husband Thomas Prowse. Prowse continued Hosier's policy of buying up freeholds in the parish, including property at Dagnall sold off by the Spencer family in the mid seventeenth century which Prowse acquired in $1753 .{ }^{53}$ Whereas there had been at least 400 acres of freehold land in the parish in 1717 , forty years later Prowse owned almost all of Wicken with the exception of the glebe, two houses and five cottages. ${ }^{54}$ Moreover he acquired at least one common right from one of the last remaining freeholders by means of exchange in $1756 .{ }^{55}$ In 1757 Prowse enclosed the open fields by means of an agreement 
with the rector of Wicken and the Bishop of Peterborough, thus obviating the need for an Act of Parliament. ${ }^{56}$

The year after the enclosure of the open fields, Prowse began work on the church at Wicken, which he had already partly demolished after the building was declared unsafe in $1753 .{ }^{57}$ Prowse was an amateur architect and he drew the designs for the new church himself, which was built entirely at his own cost. A survey of the building suggests that the nave and chancel were rebuilt on old foundations and that the west walls of the aisles were retained, along with the early seventeenth-century west tower. The new nave was constructed in a late thirteenth-century style, while the chancel was built in a late medieval Perpendicular style and included an elaborate fan vault. ${ }^{58}$

The church was still unfinished at Thomas Prowse's death in January 1767. His son George died just months later, and George's widow Elizabeth took control of the project along with the estate. Elizabeth oversaw the installation of new pews and new altar furniture in the early part of 1770, and in the autumn personally supervised the workmen as they dug a new drain around the church to stop rainwater coming in. ${ }^{59}$ The church was finished by October 1770 when Elizabeth's mother-in-law met the final costs of the project. ${ }^{60}$ Elizabeth was a committed Anglican and it was said that a bell was rung at Wicken Park as a signal for prayers. ${ }^{61}$ Alongside her personal piety and her patronage of the village church, Elizabeth attempted to stem the rise of non-conformity in the area. In 1801, she dismissed her dairymaid for attending Methodist meetings and for encouraging the youth of the village to accompany her, presumably to the house registered for Protestant dissenters at nearby Deanshanger. ${ }^{62}$

None of this is surprising given that Elizabeth came from a large but close-knit family, many of whom had served in the Church of England. Her grandfather was archbishop of York, her father archdeacon of Northumberland and two of her brothers were Anglican clergymen. Elizabeth was one of nine adult siblings, all of whom shared a great love of devotional music. The family met regularly in order to play together, either at Wicken or in London where most of her brothers were based. ${ }^{63}$ One of these meetings was the subject for Zoffany's extraordinary portrait of the family, aboard the Apollo, the sailing barge of one of Elizabeth's brothers, on the River Thames near Fulham. Elizabeth is in the centre of the picture playing the harpsichord, surrounded by her brothers and sisters and their children. ${ }^{64}$ Her youngest brother was the slavery abolitionist, Granville Sharp, and two more of her brothers William and James were involved with him in the campaign against slavery. ${ }^{65}$

Given her family connections, it is not surprising that Elizabeth took an active interest in the welfare of the local community at Wicken. She made repairs to the estate cottages in the late 1760s and seems to have felt a great deal of compassion towards the poor: for example, she noted in her memoirs how the want of blankets and sheets available to the Wicken poor in the winter of 1774 was 'beyond beliefe' ${ }^{66}$ From at least 1768, Elizabeth was supporting a day school for both boys and girls, paying for a master and mistress to teach the children. Lace made by girls appears to have made a small contribution of about five per cent to the Overseers of the Poor's accounts in the $1770 \mathrm{~s} .{ }^{67}$ In 1788 Elizabeth also started to support a Sunday school, which may have been held in the north chapel of the church. ${ }^{68}$ Moreover, she continued to support both the day and 
the Sunday schools post-mortem with the gift of a share in the Grand Junction Canal Company. ${ }^{69}$

Elizabeth held a harvest festival for her tenants and their families. In 1777, a visiting gentleman reported how the Sharp brothers and Mrs Prowse's domestic servants had met the labourers coming back with the harvest wagon, and played a march for them to process back into the village. Here they were entertained with music and dancing, along with syllabub, bread, cheese and ale. ${ }^{70}$ Other charitable acts recorded in her memoirs include providing five of her tenants with medicine after they were bitten by a rabid cat in 1776, and helping one of her gardeners get sober and repay his debts. ${ }^{71}$ Overall, it is perhaps not surprising that she was reported to be the mistress of 'the happiest set of peasants in England', as her gentleman visitor remarked in $1777 .^{72}$

Alongside patronising charitable concerns in the village, Elizabeth continued to improve the house and gardens. Her father-in-law had been a prodigious improver, but she and George had also made plans to improve the estate. As she wrote in her memoirs, on first learning that Thomas had passed the estate to them, George and Elizabeth had spent their journey back to Wicken 'forming our plans for living there'. ${ }^{73}$ Plans to extend the house had actually been drawn up by her father-in-law in 1765, but work continued for more than a decade after her husband's death, as Elizabeth's accounts demonstrate. ${ }^{74}$ Work also continued on the stables, gardens and park in the $1770 \mathrm{~s} .{ }^{75} \mathrm{~A}$ plan to drive a riding through Lilby woods was first mentioned in 1769 and completed in July 1772, when Elizabeth held a tea party in the riding for fifty guests who were entertained by the Sharp family band. ${ }^{76}$ New gravel walks were created in Park Copse in 1771 and a new riding to Deanshanger laid out in 1784 , as well as new gates put up and an area near the riding laid to grass in the same year. ${ }^{77}$

Alongside these landscaping initiatives, Elizabeth introduced a range of agricultural innovations and improvements to the estate. She kept scrupulous records about both her and her family's financial affairs and her estate ledgers for the period 1768 to 1771 and 1774 to 1784 provide good evidence that she was financing numerous agricultural improvements on the estate. For example, Elizabeth paid for repairs to barns and outbuildings on several of her tenants' farms, as well as installing pumps in at least three of the farms, in the yard and stables at Wicken Park, and in some of the estate cottages. ${ }^{78}$ She paid for a pond to be dug on one tenant's holding and contributed towards the farmers' hedging and fencing costs. ${ }^{79}$ She installed stone drains on part of the estate, paid for ditches to be dug on several of the farms and cleared parts of fields of anthills, the latter at a cost of seventy pounds. ${ }^{80}$ Elizabeth also neutralised and improved the soil by marling areas of the park, perhaps with the intention of putting the former parkland under new crop rotations including clover and turnips, while elsewhere on the estate she drained, burnt and eventually ploughed the Great Leys. $^{81}$

Entries in the estate ledgers make it clear that Elizabeth agreed to finance many of these improvements as an incentive for her tenants to convert from yearly tenancies to longer-term leases. Thus the ledgers include sums paid to the farmers when they signed their leases, as well as entries for ditching and other improvements agreed as part of the negotiations. ${ }^{82}$ For example: 
May $221769 \quad$ For trenching some ground for Farmer Adams by agreement at making his Leece $£$ 1.5.0

October 191769 To Ditching in Thomas Adams field agreed to when he took his Bargain $£ 1.16 .9$

May $11770 \quad$ Payd Farmer Turpin for seed as promised when he took his leece $£ 6.15 .0^{83}$

By March 1768, less than a year after her husband's death, Elizabeth had settled with all but one of her tenants to replace their yearly tenancy agreements with new leases. The farmer who left his farm rather than take a lease was already thought to be 'taking advantage', and it may have been his attempts to profit at the expense of the long-term quality of the land which prompted Elizabeth to suggest leases to her tenants. ${ }^{84}$

Nor was that Elizabeth's only innovation on the estate. Her brother James Sharp was a London ironmonger who invented a range of agricultural machinery including so-called rolling carriages. These had rollers instead of wheels and were designed to stop the roads becoming rutted by the passage of carts. James's rolling carriages were in use at Wicken by the winter of 1771-2, when they were used in the construction of the new riding, the stone drains and for 'carting which is all towards the improvements of the Estate'. ${ }^{85}$ In the winter of 1773 , James gained a government contract to extract timber from Whittlewood Forest using the rolling carriages, which he also used to transport coal and timber to be sold locally. ${ }^{86}$ Moreover, the carriages were being used more widely in the neighbourhood within a couple of years, as well as at Bath and Bristol by January $1774 .{ }^{87}$

Elizabeth also experimented with the crops she grew on the home farm and with animal feeds. While visiting her mother-in-law's estate at Berkeley (Gloucestershire) in June 1770, Elizabeth noted the quantities of cheese, cream and butter produced by the dairy herd ${ }^{88}$ From 1772 onwards, Elizabeth was growing cabbages on the home farm which were fed to the milk cattle in an attempt to improve the milk and cheese at the same time as saving grass and hay. She carefully recorded the number and weight of the cabbages grown on the estate and appears to have been disappointed when she compared these figures to the yields at Berkeley. ${ }^{89}$

Elizabeth died in 1810 at the age of seventy-seven, having spent more than forty years managing the estate at Wicken. During this time, she had landscaped the house and park, rebuilt the church, established the village school and improved the agricultural estate by introducing new machinery, new crops, drainage and long-term leases. Yet despite all her achievements as a capitalist and innovative farmer, it was Elizabeth's more feminine virtues that were celebrated at her funeral. In the sermon delivered on the Sunday following her funeral, Reverend John Owen emphasised her piety, charity and faithfulness to her relations and friends. He described how Elizabeth had employed pensioners and other 'victims of infirmity' on her estate, so that:

Her lawns were mown, her fields were cultivated, her garden was dressed, by those whom time had superannuated, or misfortune had crippled; and who, but for such provident kindness, must have hung upon society as pensioners, or infested it as beggars. ${ }^{90}$ 
This is of course potentially ironic, given that enclosure and the buying up of freehold land by Elizabeth's predecessors may have increased the numbers of paupers dependent on her charity.

Like many wealthy women, the widows discussed in this paper were all involved in charitable and educational projects which benefited the poor. For example, Lady Elizabeth Dryden gave a yearly sum to charity and Mrs Jane Ashley paid for the schooling of several local children as well as held an annual Christmas dinner for her cottage tenants and another for the village poor. ${ }^{91}$ Lady Dryden left bequests to the poor of local parishes and to the County Hospital at Northampton, while Jane Ashley established a charity in her will to distribute meat and coals to the poor at Christmas, flour to paupers on Shrove Tuesday and gifts to poor children on Valentine's Day. ${ }^{92}$ Elizabeth Prowse's philanthropy seems to have been informed by an awareness that the social and economic costs of enclosure and estate improvement were often borne disproportionately by the poorest in society. In her memoirs, she quotes an extract from Nathaniel Kent's General View of the Agriculture of the County of Norfolk which draws attention to the high costs of feeding draught animals, especially horses, compared to the poor. The extract concludes, 'So one of these horses eats nearly as much as 5 men, therefore if we reduce the horses the more plentiful fruits of the earth for man', thus demonstrating an explicit concern about the impact of agricultural improvement on the poor. ${ }^{93}$ In this sense, Elizabeth arguably exhibited a specifically feminine spirit of estate improvement which combined personal piety and benevolence towards the community with a desire to profit from enclosure and agricultural rationalisation.

Moreover while Elizabeth both continued and significantly extended her father-inlaw's programme of improvements, she was nevertheless sometimes critical of the things that he had done in the name of progress. We get a further inkling of her potentially ambivalent attitude to improvement from the Grafton Park notebook. Here she records how her father-in-law had cut down the avenue at Grafton Park and drained, or, as she put it, 'destroyed', the pond. ${ }^{94}$ She clearly disapproved of his decision to cut down the trees, noting how the avenue had given the previous landowner particular pleasure. It is really little more than a brief insight into her attitude to estate improvement, and we are left to wonder what she and the other women discussed here thought about their own place in the enclosure movement and the changes it wrought on the physical and social landscape around them.

\section{Conclusions}

In his funeral sermon Reverend Owen described Elizabeth Prowse as a 'mirror of her sex'. ${ }^{95} \mathrm{He}$ meant this in the sense that she was a model to be imitated by others in his congregation, but we might usefully employ this phrase to consider how far widows like Elizabeth were representative of elite women more generally. The documentary sources for Elizabeth Prowse are particularly rich, but evidence has been presented here to demonstrate the active involvement of three more women in estate management and improvement in later eighteenth-century Northamptonshire. Women like Jane Ashley, Elizabeth Dryden and Mary Cotterel personally collected rents, kept detailed estate 
ledgers, lobbied parliament for enclosure acts and negotiated with freeholders about purchases and exchanges. In the wake of enclosure, they reorganised tenancies and improved their tenants' farmsteads and cottages, as well as invested in hedging, drainage and marling. Elizabeth Prowse was an innovative landowner who experimented with new agricultural machinery, crops and rotations, both on the home farm and on the wider estate. All this was done in the hope of profiting from improved agricultural rents, and in this sense these were women who not only maintained the financial viability of the estate, but also created wealth which could be handed on to their sons, daughters or other more distant relatives.

Moreover, there were other women who took control of landed estates in Northamptonshire in the second half of the eighteenth century, but the vagaries of document survival mean less is known about them. For example, the widowed Lady Juliana Langham of Cottesbrooke bought estates at Stoke Doyle and Winwick in the mid 1790s. ${ }^{96}$ She had visited Thomas Coke's Holkham estate in 1782, but the documentary sources are not available to tell us whether she put into practice in Northamptonshire any of the agricultural improvements she witnessed in Norfolk. ${ }^{97}$ Much the same is true of Lady Betty Germain, the widow of the Dutch soldier and adventurer Sir John Germain, who held an estate at Drayton (parish Lowick) for over fifty years between 1718 and $1769 .{ }^{98}$ In 1732, she was leasing part of the estate on twenty-one-year leases which specified the rotations to be followed and prohibited the conversion of grass to arable. She also appears to have extended the park in the 1730s, but the almost complete lack of eighteenth-century documents in the family archive make it difficult to say more about her management of the estate. ${ }^{99}$

Most of the women mentioned in this paper did not have children and it is their childlessness which improves their visibility in the historical record. While widows escaped the legal anonymity of coverture, those with children did not normally take over management of the main estate except for relatively short periods of time until their eldest son came of age. By contrast, the childless widows discussed here had rights for life in some or all of their dead husband's property and managed their estates for decades rather than years, hence their visibility in the sources. However, it may be that many more women than we think were actively involved in estate management, not only as widows but also as married women in their husbands' lifetimes. Many men would have spent time away from home on business or in parliament, and those women who stayed at home in their husband's absence must surely have been involved in managing the estate. Yet their presence on the home farm tends to be eclipsed by their husbands' presence in the documents. Lady Dryden's account books are an important reminder to us to eschew the assumption that it was men, whether husbands or stewards, who kept ledgers and accounts, and to analyse accounts, rentals and other sources for evidence of married women's contribution to managing landed estates.

Despite the difficulties in accessing women's histories, the evidence presented in this paper demonstrates that propertied women did not universally retire into the private, domestic sphere in the later eighteenth century. Instead, women like Elizabeth Prowse, Jane Ashley and Elizabeth Dryden embraced their traditional roles as domestic managers and community patrons at the same time as pursuing more capitalist concerns to enclose 
the open fields, rationalise the estate and profit from improved agricultural rents. That female landowners' presence on their estates upsets modern notions of distinct gender roles and spaces for early modern men and women perhaps explains why historians have been slow to recognise elite women's involvement in enclosing and improving their estates. My hope is that this paper goes some way towards re-evaluating and securing eighteenth-century women's rightful place in the history of parliamentary enclosure and landscape improvement.

\section{Acknowledgements}

I would like to thank Matthew Cragoe, Owen Davies and the anonymous referees for their valuable comments on the paper and the staff of the Northamptonshire and Gloucestershire record offices for their help. An earlier version of the paper was given at the Land, Landscape and Environment conference at the University of Reading on 15th July 2008.

\section{Notes}

1. K. Gleadle and S. Richardson, eds., Women in British Politics, 1760-1860: The Power of the Petticoat (Basingstoke, 2000); A. K. Mellor, Mothers of the Nation: Women's Political Writing in England, 1780-1830 (Bloomington, 2000); H. Rogers, Women and the People: Authority, Authorship and the Radical Tradition in Nineteenth-Century England (Aldershot, 2000); E. Chalus, 'Kisses for Votes: The Kiss and Corruption in Eighteenth-Century English Elections', in K. Harvey, ed., The Kiss in History (Manchester, 2005), pp. 122-47; C. Midgley, Feminism and Empire: Women Activists in Imperial Britain, 1790-1865 (London, 2007), pp. 41-86.

2. L. Davidoff and C. Hall, Family Fortunes: Men and Women of the English Middle Class, 1780 1850 (Chicago, 1987); S. Walker, 'How to Secure your Husband's Esteem: Accounting and Private Patriarchy in the British Middle-Class Household during the Nineteenth Century', Accounting, Organizations and Society 23:5-6 (1998), 485-514; H. Barker, The Business of Women: Female Enterprise and Urban Development in Northern England, 1760-1830 (Oxford, 2006); N. J. Phillips, Women in Business, 1700-1850 (Woodbridge, 2006); C. Wiskin, 'Business Women and Financial Management: Three Eighteenth-Century Case Studies', Accounting, Business and Financial History 16:2 (2006), 143-61. For women's involvement in lending, see B. A. Holderness, 'Widows in Pre-Industrial Society: An Essay upon their Economic Functions', in R. M. Smith, ed., Land, Kinship and Life-Cycle (Cambridge, 1984), pp. 42342; J. Spicksley, 'Usury Legislation, Cash and Credit: The Development of the Female Investor in the Late Tudor and Stuart Periods', Economic History Review, 61:2 (2008), 277-301, who highlights single women's increasing involvement in formal credit provision and the contribution they thereby made to an expanding economy in the century up to 1760. For eighteenth-century examples, see B. A Holderness, 'Elizabeth Parkin and her Investments, 1733-66: Aspects of the Sheffield Money Market in the Eighteenth Century', Transactions of the Hunter Archaeological Society, 10 (1979), 81-7; P. Sharpe, 'Dealing with Love: The Ambiguous Independence of the Single Woman in Early Modern England', Gender and History, 11 (1999), 209-32; P. Sharpe, 'A Woman's Worth: A Case Study of Capital Accumulation in Early Modern England', Parergon, 19 (2002), 173-84.

3. D. R. Green and A. Owens, 'Gentlewomanly Capitalism? Spinsters, Widows and Wealth Holding in England and Wales, c. 1800-1860', Economic History Review, 56:3 (2003), 510-36; C. Wiskin, 'Industry, Investment and Consumption: Urban Women in the Midlands', in J. Stobart and N. Raven, eds., Towns, Regions and Industries: Urban and Industrial Change 
in the Midlands, c. 1700-1840 (Manchester, 2005), pp. 62-79, citing S. Hudson, 'Attitudes to Investment Risk among West Midland Canal and Railway Company Investors 17001850' (unpublished doctoral thesis, University of Warwick, 2001), p. 113; J. Rutterford and J. Maltby, “The widow, the clergyman and the reckless": Women Investors in England, 1830-1914', Feminist Economics, 12:1-2 (2006), 111-138.

4. N. Verdon, ““... subjects deserving of the highest praise”: Farmers' Wives and the Farm Economy in England, c.1700-1850', Agricultural History Review, 51:1 (2003), 23-39. See also A. Clark, Working Life of Women in the Seventeenth Century (London, 1919), pp. 5, 50, 60-62; M. Roberts, 'Sickles and Scythes: Women's Work and Men's Work at Harvest Time', History Workshop Fournal, 7 (1979), 3-28; B. Hill, Women, Work and Sexual Politics in Eighteenth-Century England (Oxford, 1989), pp. 24-46; D. Valenze, 'The Art of Women and the Business of Men: Women's Work and the Dairy Industry c. 1740-1840', Past and Present, 130 (1991), 142-69.

5. I. Pinchbeck, Women Workers and the Industrial Revolution, 1750-1850 (London, 1930), pp. 59-63 and 84-6; K. Snell, 'Agricultural Seasonal Employment, the Standard of Living, and Women's Work in the South and East 1690-1860', Annals of the Labouring Poor: Social Change and Agrarian England, 1660-1900 (Cambridge, 1985), pp. 15-66; J. Burnette, 'The Wages and Employment of Female Day-Labourers in English Agriculture, 1740-1850', Economic History Review, 57:4 (2004), 664-90; P. Sharpe, 'The Female Labour Market in English Agriculture during the Industrial Revolution', in N. Goose, ed., Women's Work in Industrial England: Regional and Local Perspectives (Hatfield, 2007), pp. 51-75; N. Verdon, 'Hay, Hops and Harvest: Women's Work in Agriculture in Nineteenth-Century Sussex', in Goose, ed., Women's Work, pp. 76-96.

6. S. G. Bell, 'Women Create Gardens in Male Landscapes: A Revisionist Approach to Eighteenth-Century English Garden History', Feminist Studies, 16:3 (1990), 471-91. Examples of recent work on women and gardens include A. Hunt and P. Everson 'Sublime Horror: Industry and Designed Landscape in Miss Wakefield's Garden at Basingill, Cumbria', Garden History, 32:1 (2004), 68-86 on the gardens created by Isabella Wakefield; L. L. Moore 'Queer Gardens: Mary Delany's Flowers and Friendships', Eighteenth-Century Studies, 39:1 (2005), 49-70.

7. A. Vickery, The Gentleman's Daughter: Women's Lives in Georgian England (London, 1998), pp. 9 and 127; W. Stafford, 'The Gender of the Place: Buildings and Landscape in WomenAuthored Texts in England of the 1790s', Transactions of the Royal Historical Society, 13 (2003), 305-18, p. 312 also cautions against belittling the role played by women in managing the domestic household.

8. R. Larsen, 'For Want of a Good Fortune: Elite Single Women's Experiences in Yorkshire, 1730-1860', Women's History Review, 16:3 (2007), 387-401; S. Tillyard, Aristocrats: Caroline, Emily, Louisa and Sarah Lennox 1740-1832 (London, 1995), pp. 352 and 411-2; T. Lummis and J. Marsh, The Woman's Domain: Women and the English Country House (London, 1990), pp. 91-118. Elizabeth Chute's involvement in charitable projects contrasts strongly with the actions of her nephew who, when he inherited the estate in 1827, began to dispossess smallholders in order to enclose and amalgamate the farms. He later attempted to solve spiralling poor rates by organising for the poor of the parish to emigrate to Canada.

9. A. L. Erickson, 'Possession - and the Other One-Tenth of the Law: Assessing Women's Ownership and Economic Roles in Early Modern England', Women's History Review, 16:3 (2007), 369-85; J. Bailey 'Favoured or Oppressed? Married Women, Property and "Coverture" in England, 1660-1800', Continuity and Change, 17:3 (2002), 351-72. For a contrasting view, see E. Spring, Law, Land and Family (Chapel Hill, North Carolina, 1993) who points to a long-term decline in women's property and rights which reached their lowest ebb in the eighteenth century. In particular, she argues that widows 'ceased to be of consequence in landholding' as a result of the increasing use of prenuptial contracts in the early modern period (p. 64). 
10. Vickery, Gentleman's Daughter, p. 2 reviews the literature; Hill, Women, Work, p. 123; L. Stone, The Family, Sex and Marriage in England, 1500-1800 (London, 1977), p. 396; S. W. Amussen, An Ordered Society: Gender and Class in Early Modern England (Oxford, 1988), p. 187; C. Hall, 'The History of the Housewife' in C. Hall, White, Male and Middle Class: Explorations in Feminism and History (Cambridge, 1992), pp. 43-71. See J. Thomas 'Women and Capitalism: Oppression or Emancipation? A Review Article', Comparative Studies in Society and History, 30:3 (1988), 534-49 for a review of some of the early literature on the impact of capitalism on women's position in society.

11. J. Humphries, 'Enclosures, Common Rights, and Women: The Proletarianization of Families in the Late Eighteenth and Early Nineteenth Centuries', Fournal of Economic History, 50:1 (1990), 17-42; Hill, Women, Work, pp. 49-54 and 60-2; C. Middleton, 'Women's Labour and the Transition to Pre-Industrial Capitalism', in L. Charles and L. Duffin, eds., Women and Work in Pre-Industrial England (London, 1985), pp. 181-206; J. Rendall, Women in an Industrialising Society: England, 1750-1880 (Oxford, 1990), p. 13; Snell, 'Agricultural Seasonal Employment', pp. 15-66; Pinchbeck, Women Workers, p. 41. See also S. Horrell and J. Humphries, 'Women's Labour Force Participation and the Transition to the Male Bread-Winner Family, 1790-1865', Economic History Review, 48:1 (1995), 89-117.

12. R. Jones and M. Page, Medieval Villages in an English Landscape: Beginnings and Ends (Macclesfield, Cheshire, 2006), pp. 18, 139 and 214-9; Victoria County History: Northamptonshire V: Cleley Hundred (Woodbridge, Suffolk, 2002), pp. 414-6; J. M. Steane, The Northamptonshire Landscape (London, 1974), pp. 25-9.

13. J. W. Anscomb, Northamptonshire Inclosure Acts and Awards (unpublished, n.d, at NRO).

14. I am grateful to Tom Williamson and Tracey Partida for bringing this 'double peak' pattern to my attention in a paper entitled 'Explaining the Chronology of Enclosure: The Example of Northamptonshire' delivered at Rewley House, Oxford on 17th May 2008.

15. For definitions of the English aristocracy, see J. V. Beckett, The Aristocracy of England, 16601914 (Oxford, 1986), p. 23 and F. M. L. Thompson, English Landed Society in the Nineteenth Century (London, 1963), pp. 25-44.

16. A. L. Erickson, Women and Property in Early Modern England (London, 1995), p. 25.

17. Vickery, Gentleman's Daughter, pp. 97 and 313.

18. O. Barron, Northamptonshire Families, Vol III (London, 1906), p. 371; Northamptonshire Record Office (hereafter NRO) archive collections list.

19. NRO, ASL 357 and 362.

20. See for example GRO, D3549/14/1/2 part 3, p. 58.

21. GRO, D3549/14/1/2 part 3, pp. 91 and 93.

22. GRO, D3549/14/1/2 part 3, p. 41.

23. GRO, D3549/14/1/5.

24. GRO, D3549/14/1/2 part 3, pp. 29 and 37.

25. NRO, D(CA) 1030.

26. NRO, D(CA) 1031.

27. NRO, D(CA) 1031, 1034 and 1037.

28. NRO, D(CA) 1032.

29. NRO, D(CA) 531.

30. N. Cooper, Aynho: A Northamptonshire Village (Banbury, 1984), pp. 314-5; Barron, Northamptonshire Families, Vol III, p. 376.

31. GRO, D3549/14/1/2 part 3, p. 25.

32. NRO, 364p/61, 67-70 and 501 .

33. NRO, D(CA) 1031.

34. NRO, D(CA) 322.

35. NRO, D(CA) 321.

36. NRO, D(CA) 321 and 746. Emphasis added. 
37. NRO, 364p/501. The book is wrongly attributed to Elizabeth (Betsy) Mordaunt (née Prowse) in a typed note at the front of the volume.

38. NRO, 364p/61.

39. GRO, D3549/14/1/2 part 3, pp. 30, 45 and 74 .

40. Data based on Anscomb, Northamptonshire Inclosures.

41. Samuel Harris had served the Ashley family as their London-based lawyer from the early 1750s, while his brother Thomas was acting as steward for the Ashley estates from at least 1757. As well as serving them in a professional capacity, the Harris brothers appear to have enjoyed a personal relationship with both John and Jane Ashley, who amongst other things provided breakfasts, horses and accommodation for Samuel Harris's sons as they travelled to and from boarding school in Rugby in the mid 1750s (NRO, ASL 1122; M(F) 30 and 32).

42. NRO, M(F) 879 .

43. NRO, M(F) 75, 77-80 and 87.

44. NRO, M(F) 83 .

45. S. Hindle, 'Gossip, Gender and the Experience of Authority in Early Modern England', Continuity and Change, 9:3 (1994), 391-419.

46. NRO, M(F) 165 and 166. The undated rental was made for Jane's brother-in-law Solomon Ashley and was drawn up after 1754 when Mand arrived as vicar and before 1771 when Robert Verney gave up his farm. The most likely date is soon after the death of John Ashley in 1761, when Solomon became heir to the estate.

47. NRO, ASL 165 and 363.

48. VCH Nhants V, pp. 161-2.

49. NRO, C(A) 8380, 8398 and 8401; Cooper, Aynho, pp. 178 and 314-5.

50. NRO, C(A) 8408, 8458, 8840 and enclosure volume I, p. 439; Cooper, Aynho, pp. 179 and 182. On Mary and Stephen's role as deputies to William, see also NRO, C(A) 8477 where Stephen reported to William that 'on the subject of the new inclosures, I find him [Robert Weston, the Aynho steward] very anxious to see you, or at least us'.

51. NRO, H(W) 47-61.

52. VCH Nhants V, p. 416.

53. NRO, $\mathrm{H}(\mathrm{W}) 111$ and 133.

54. NRO, 364p/65; H(W)65. The figures for the freehold land are drawn from a copy of the 1717 terrier. The accompanying map gives slightly different figures.

55. NRO, H(W)62.

56. The three men undertook to obtain an Act of Parliament to confirm their agreement, though they apparently never did so (NRO, 364p/14).

57. NRO, $364 \mathrm{p} / 28$.

58. I am grateful to Carol Davidson Cragoe of English Heritage for her help examining the standing fabric of the church.

59. NRO, 364 p/30 and GRO, D3549/14/1/2 part 3, pp. 32 and 36 .

60. GRO, D3549/14/1/2 part 3, p. 36; NRO, 364p/30.

61. GRO, D3549/12/1/4.

62. GRO, D 3549/14/1/2, p. 98; VCH Nhants V, p. 237

63. GRO, D3549/14/1/2, part 3, pp. 2-3; B. Crosby, Private Concerts on Land and Water: The Musical Activities of the Sharp Family, c.1750-c.1790, Royal Musical Association Research Chronicle 34 (2002), passim.

64. J. Kerslake, 'A Note on Zoffany's "Sharp Family”, The Burlington Magazine, 120: 908 (1978), $753-4$

65. G. M. Ditchfield, 'Sharp, Granville (1735-1813)', Oxford Dictionary of National Biography, Oxford University Press, September 2004; online edn, January 2008 [http://www. oxforddnb.com/view/article/25208, accessed 30 April 2008].

66. NRO, 364p/67, f. 15; GRO, D3549/14/1/2 part 3, p. 49. 
67. NRO, 364p/67, f. 122 and 364p/39.

68. GRO, D3549/14/1/2 part 3, p. 74; NRO, 364p/501.

69. NRO, $364 \mathrm{p} / 48$.

70. GRO, D3549/12/1/4.

71. GRO, D5349/14/1/2 part 3, pp. 54 and 52 .

72. GRO, D3549/12/1/4.

73. GRO, D5349/14/1/2 part 3, p18.

74. GRO, D3549/14/1/2 part 3, p. 19; NRO, 364p/67-9, passim.

75. GRO, D3549/14/1/2 part 3, pp. 60 and 91; NRO, 364p/67-9, passim.

76. GRO, D3549/14/1/2 part 3, pp. 30 and 91.

77. GRO, D3549/14/1/2 part 3, pp. 37 and 68.

78. NRO, 364p/67, ff. 15, 40 and 120-134; /68, f. 197; and 364p/501.

79. NRO, 364p/67, ff. 121 and 120-134, passim; /68, ff. 189, 192 and 196.

80. NRO, 364p/67, f. 123; /68, ff. 190, 192, 200 and 202.

81. GRO, D3549/14/1/2 part 3, p. 40; NRO, 364p/68, ff. 196 and 199; T. Williamson, The Transformation of Rural England: Farming and the Landscape, 1700-1870 (Exeter, 2002), pp. $67-8$.

82. NRO, $364 \mathrm{p} / 67$, f. 120.

83. NRO, 364p/67, ff. 123, 124 and 128.

84. GRO, D5349/14/1/2 part 3, p. 27. None of these leases survive, but entries in the estate ledgers suggest that some were for seven years. For example, farmer Turpin replaced Battam in 1768 and took a new lease in June 1775 (NRO, 364p/67, ff. 120-1 and 128; /68, f. 194).

85. NRO, 364p/68, ff. 190, 194 and 199; GRO, D3549/14/1/2 part 3, p. 40.

86. GRO, D3549/14/1/2 part 3, p. 41.

87. GRO, D5349/14/1/2 part 3, pp. 40-1 and 12/1/6.

88. GRO, D3549/14/1/2 part 3, pp. 34 and 46.

89. GRO, D5349/14/1/2 part 3, pp. 43 and 46.

90. GRO, D5349/13/5/33, p. 13-4.

91. NRO, D(CA) 322, passim and 533; ASL 1226.

92. NRO, ASL 351.

93. Elizabeth had no particular connections to Norfolk, but it seems possible that she had met Kent in Fulham in the winter of 1791. The General View of Norfolk was not published until 1796 but the quotation in Elizabeth's memoirs appears after an entry dated December 12th 1791 noting how she and her sister Frances spent the winter in Fulham. Elizabeth's brother William Sharp lived at Stourton House on the High Street in Fulham, about $0.7 \mathrm{~km}$ from Kent who rented Colehill Cottage, just off Fulham Palace Road (GRO, D5349/14/1/2, pp. 85-6; P. Horn, 'An Eighteenth-Century Land Agent: The Career of Nathaniel Kent (1737-1810)', Agricultural History Review, 1-16, p. 4 note; Kerslake, 'Sharp Family', p. 754).

94. NRO, $364 \mathrm{p} / 61$.

95. GRO, D5349/13/5/33, p. 20.

96. NRO, C(S)166.

97. NRO, L(C)922.

98. A. P. Baker, 'Germain, Lady Elizabeth [Betty] (1680-1769)', Oxford Dictionary of National Biography, Oxford University Press, 2004 [http://www.oxforddnb.com/view/article/10565, accessed 28 July 2008].

99. NRO, SS3866. Of the more than 4,000 documents in the Stopford Sackville collection at the NRO, only four relate to Lady Germain's period of ownership. 